\title{
Synthesis and characterization of a substituted indolizine and investigation of its photoluminescence quenching via electron- deficient nitroaromatics
}

\author{
Mustafa K. Bayazit*ab and Karl S. Coleman ${ }^{\mathrm{a}}$ \\ ${ }^{a}$ Department of Chemistry, University of Durham, Durham DH1 3LE, UK \\ ${ }^{b}$ Department of Chemistry, Imperial College London, London SW7 2AZ, UK \\ E-mail: m.bayazit@imperial.ac.uk
}

DOI: http://dx.doi.org/10.3998/ark.5550190.0015.500

\begin{abstract}
Synthesis, characterization and the direct use of dimethyl 3-(4-aminophenyl)indolizine-1,2dicarboxylate (1) as a photochemical sensor for the solution phase detection of nitroaromatics are presented. Fluorescent quenching experiments depict that nitroaromatics, particularly nitrophenol derivatives, may be probed by diester 1 with a detection limit of $6.66 \times 10^{-8} \mathrm{M}$. FTIR and ${ }^{1} \mathrm{H}$ NMR studies together with fluorescent spectral analysis suggest that H-bonding interaction between 1 and $p$-nitrophenol (2d) triggers the formation of ground-state complex (1:2d) which causes the fluorescent quenching via electron transfer from the HOMO of electron-rich indolizine to the LUMO of electron-deficient nitrophenolics through hydrogen bonding.
\end{abstract}

Keywords: Indolizine, 1,3-dipolar cycloaddition, fluorescence quenching, photochemical sensor, nitroaromatics

\section{Introduction}

Detection of nitroaromatics is important both in terms of homeland security and environmental monitoring since they are present in explosive warfare agents including trinitrotoluene (TNT) and ammonium picrate (dunnite), and pollute the environment. There is an increasing demand to develop sensing devices to monitor trace nitroaromatics especially nitrophenols due to their toxicity upon inhalation and ingestion since they have been listed as potential pollutants by U.S. Environmental Protection Agency. ${ }^{1}$ Indolizine derivatives are particularly interesting as they are well known for exhibiting a variety of pharmacologically desirable properties, including cardiovascular, anti-inflammatory and antioxidant properties, ${ }^{2}$ as well as having known fluorescent properties and being used in sensor application. ${ }^{3-5}$ Indolizine derivatives bearing $\beta$ cyclodextrin groups have mostly been used for the detection of organic volatile compounds including phenol, p-cresol, 1-adamantanol and 1-adamantonoic acid due to the inclusion 
capability of cyclodextrins. ${ }^{6,7}$ However, to the best of our knowledge, no experimental data has yet been released showing the photochemical fluorescence quenching of indolizines via the direct interaction of quest compounds with main indolizine skeleton. In this paper, an indolizine based photochemical sensor has been presented to detect nitroaromatics in solution phase, with higher affinity towards nitrophenols. Structure of indolizine is enlightened by FTIR, ${ }^{1} \mathrm{H}$ NMR, ${ }^{13} \mathrm{C}$ NMR spectroscopy, and mass spectrometry. Interaction between indolizine and aromatic compounds is probed using FTIR and NMR spectroscopy and, the detection limit of photochemical sensor is provided by fluorescence quenching experiments using fluorescence spectroscopy.

\section{Results and Discussion}

The title compound $\mathbf{1}$ was prepared via the reduction of $\mathbf{5}$ using $\mathrm{Sn} / \mathrm{HCl}$. Indolizine $\mathbf{5}$ was formed by first generating the simple Kröhnke salt, $N$-(4-nitrobenzyl)-pyridinium bromide (4), followed by reaction with triethylamine and dimethyl acetylenedicarboxylate (DMAD) (Scheme 1). ${ }^{8,9}$

a)

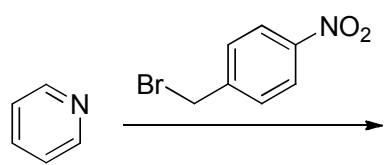

3

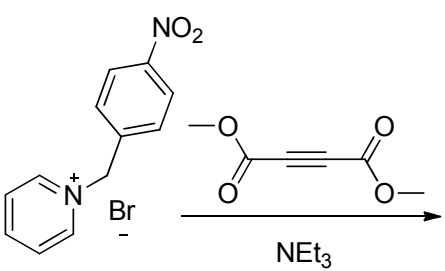

4

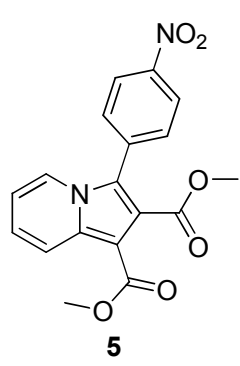

$37 \%$

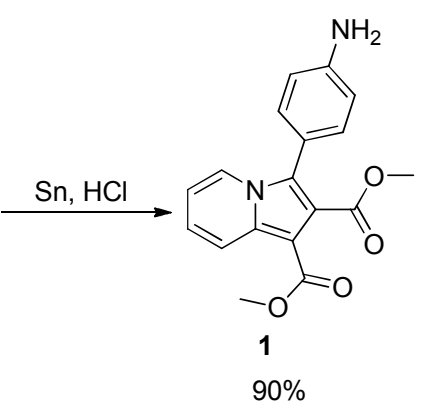

$90 \%$

b)<smiles>Oc1ccccc1</smiles>

$2 a$<smiles>O=[N+]([O-])c1ccccc1O</smiles>

$2 b$<smiles>O=[N+]([O-])c1cccc(O)c1</smiles>

2c<smiles>O=[N+]([O-])c1ccc(O)cc1</smiles>

2d<smiles>Cc1ccc([N+](=O)[O-])cc1</smiles>

$2 e$<smiles>Cc1ccc([N+](=O)[O-])cc1[N+](=O)[O-]</smiles>

$2 f$

Scheme 1. a) Schematic representation of the synthetic route for indolizine (1) b) Aromatic guest compounds (2a-f) used in study.

Excitation of 1 at $330 \mathrm{~nm}$ displayed a blue emission at $458 \mathrm{~nm}$ in acetonitrile. However no sign of fluorescence was recorded from guest compounds (2a-f). (See ESI Figure S12) Fluorescence quantum yield of $\mathbf{1}$ was calculated as 0.035 using corrected fluorescence spectra (anthracene dissolved in ethanol as a standard $\left(\Phi_{\mathrm{f}}^{\mathrm{st}}=0.27\right.$ at $\left.\left.25{ }^{\circ} \mathrm{C}\right)\right) .{ }^{10}$ Sensing ability of $\mathbf{1}$ was 
tested by aromatic guest compounds, phenol (2a), o-nitrophenol (2b), $m$-nitrophenol (2c), $p$ nitrophenol (2d), $p$-nitrotoluene (2e) and 2,4-dinitrotoluene (2f) (Figure 1).
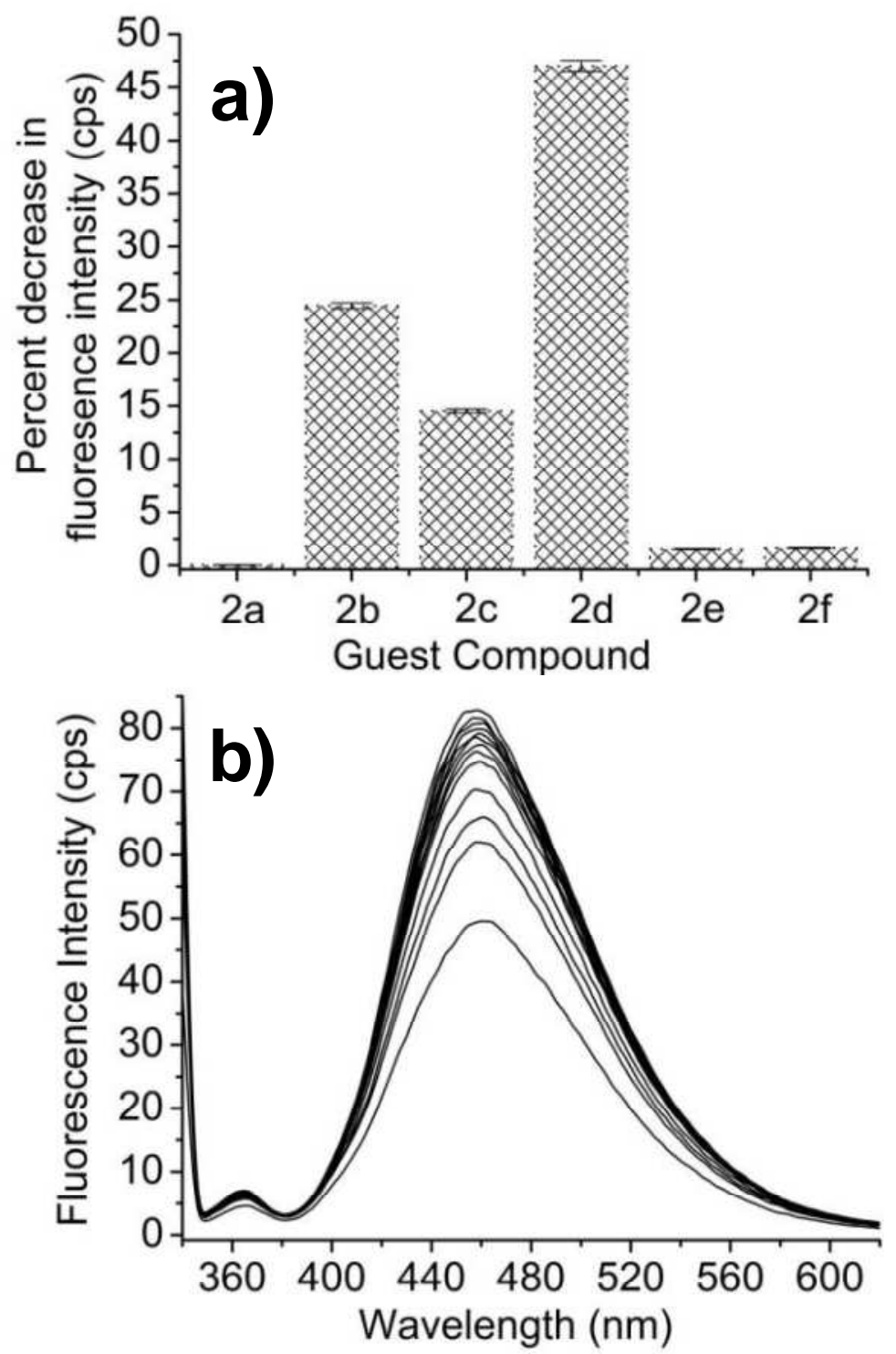

Figure 1. (a) Percent decrease in fluorescence intensity of $1(0.209 \mu \mathrm{M})$ upon the addition of $(6.250 \mu \mathrm{M})$ 2a-f. (b) Fluorescence spectra (excitation at $330 \mathrm{~nm})$ of $\mathbf{1}(0.209 \mu \mathrm{M})$ in $\mathrm{CH}_{3} \mathrm{CN}$ in the presence of $0.066,0.133,0.199,0.265,0.332,0.497,0.662,0.826,1.639,2.439,3.225$ and $6.250 \mu \mathrm{M}$ of $2 \mathrm{~d}$ pre-dissolved in $\mathrm{CH}_{3} \mathrm{CN}$.

A literature method reported by She et al. has been followed to evaluate the solution phase photochemical sensing properties of $\mathbf{1}^{11}$ Stock solution of $\mathbf{1}\left(2.09 \times 10^{-7} \mathrm{M}\right)$ and the guest molecules (2a-f) $\left(1 \times 10^{-4} \mathrm{M}\right)$ were prepared in $\mathrm{CH}_{3} \mathrm{CN}$ for fluorescence spectral analysis. 
Fluorescence response of $\mathbf{1}$ to quenchers was tested by adding known amount of aromatic compound (2a-f) (30 equiv, $62.5 \times 10^{-7} \mathrm{M}$ ). Aromatic nitrophenol derivatives (2b-d) caused a significant decrease in the fluorescence intensity of $\mathbf{1}$ compared to phenol and nitrobenzene derivatives (2a, e and $\mathbf{f}$ ) (Figure 1).

Photoluminescence quenching by nitroaromatics, which follows the optical excitation that produces an electron-hole pair, is usually attributable to electron-transfer quenching occurring from the excited molecule to the LUMO of the electron-deficient nitroaromatic molecule. In order to examine electron transfer theoretically HOMO-LUMO energies of 1 and 2a-f were predicted using extended Hückel method (Figure 2). ${ }^{12}$

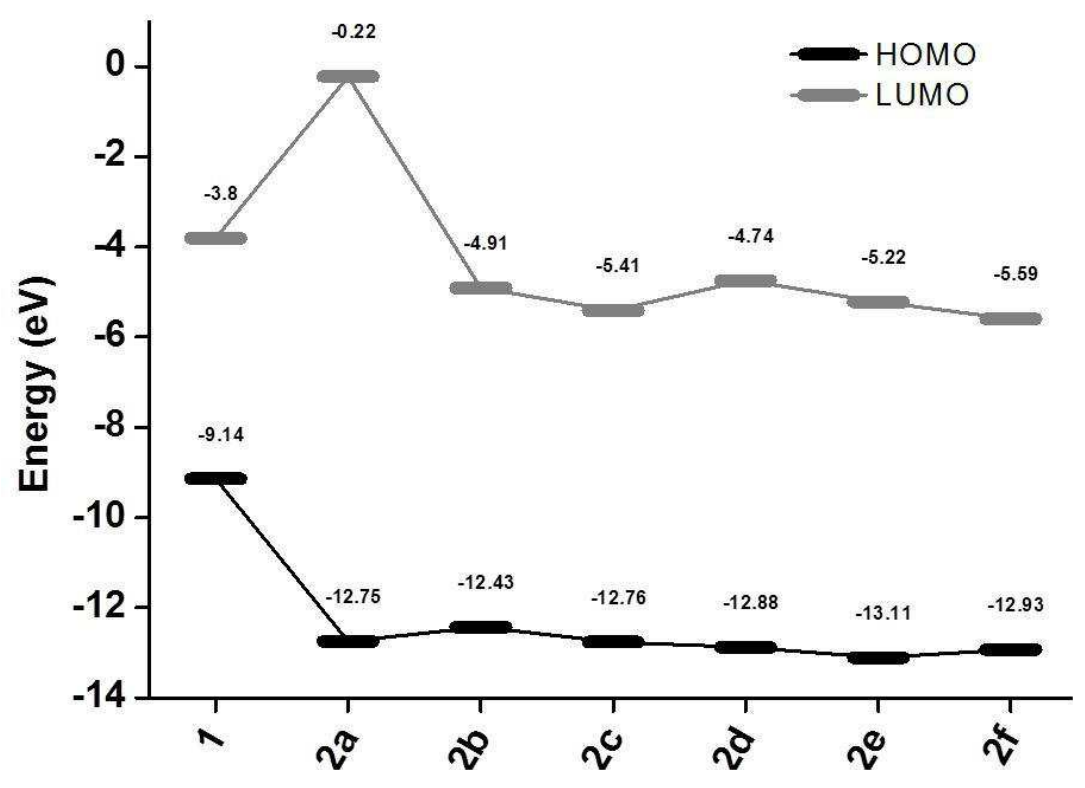

Figure 2. Comparison of HOMO—LUMO energy levels of $\mathbf{1}$ and 2a-f.

A $\mathrm{HOMO}_{1}-\mathrm{LUMO}_{2 \mathbf{a}}$ energy gap $(8.92 \mathrm{eV})$ was found to be the largest compared to $\mathrm{HOMO}_{1}-\mathrm{LUMO}_{(\mathbf{2 b}-\mathbf{f})}$ energy gap indicating electron-transfer from $\mathrm{HOMO}_{1}$ to $\mathrm{LUMO}_{2 \mathrm{a}}$ is difficult than the others. Theoretical predictions obtained for $2 \mathbf{a}$ were in agreement with the fluorescent quenching data. However, decrease in fluorescent intensity of $\mathbf{1}$ did not show the same trend upon addition of $\mathbf{2 e}$ and $\mathbf{2 f}$ although they have similar HOMO-LUMO energy gaps $\left(\mathrm{HOMO}_{1}-\mathrm{LUMO}_{2 \mathrm{e}}(3.92 \mathrm{eV}) / \mathrm{HOMO}_{1}-\mathrm{LUMO}_{\mathbf{2 f}}(3.55)\right)$ compared to $\mathbf{2 b}, \mathbf{2 c}$ and $\mathbf{2 d}$ $\left(\mathrm{HOMO}_{1}-\mathrm{LUMO}_{2 \mathbf{b}}(4.23 \mathrm{eV}) / \mathrm{HOMO}_{1}-\mathrm{LUMO}_{2 \mathbf{c}}\right.$ (3.73)/ $\mathrm{HOMO}_{1}-\mathrm{LUMO}_{2 \mathbf{d}}$ (4.40)). This was attributed to H-bonding interaction. Consistent with the previous literature, ${ }^{13,14}$ it is believed that H-bonding helps electron-transfer quenching in the present case.

Given the highest ability of $\mathbf{2 d}$ to quench the fluorescence of $\mathbf{1}$ this process was further investigated performing binding experiments. In a typical binding experiment, $3 \mathrm{~mL}$ solution of $\mathbf{1}$ was filled in a quartz cell of $1 \mathrm{~cm}$ optical path length, and stock solution of $\mathbf{2 d}(0.066,0.133$, 
$0.199,0.265,0.332,0.497,0.662,0.826,1.639,2.439,3.225$ and $6.250 \mu \mathrm{M}$ ) was added each time into quartz cell. Excitation wavelength of $330 \mathrm{~nm}$ and temperature of $25{ }^{\circ} \mathrm{C}$ were employed in all experiments. (See ESI Figure S13-17 for binding titration data of (2a-c, e and f)) Regular decrease in the corrected fluorescence intensity of $\mathbf{1}$ demonstrated the response of $\mathbf{1}$ after each addition of $2 \mathbf{d}$ (Figure 1). From binding data, detection limit was calculated as $6.60 \times 10^{-8} \mathrm{M}$ for 2d. Similar quenching profile was also observed in the case of $\mathbf{2 b}$ and $\mathbf{2 c}$ addition. (See ESI Figure S14-15 for binding titration data of $\mathbf{2 b}$ and $\mathbf{2 c}$ ) However fluorescence intensity of $\mathbf{1}$ did not show a regular decreasing trend upon addition of $\mathbf{2 a}, \mathbf{2 e}$ and $\mathbf{2 f}$ suggesting that the little change in fluorescence intensity was probably related to weak host-guest interactions including $\pi-\pi$ stacking.

Stern-Volmer plot constructed by binding experiment data provided after each addition of $\mathbf{2 d}$ to 1 showed slightly upward deviation from the linearity (Figure 3). This kind of upward curvature might be attributed to ground-state complex formation which triggers static and dynamic quenching processes. ${ }^{13-15}$ Thus, it is anticipated that fluorescent intensity of $\mathbf{1}$ might decrease as a result of a complex formation.

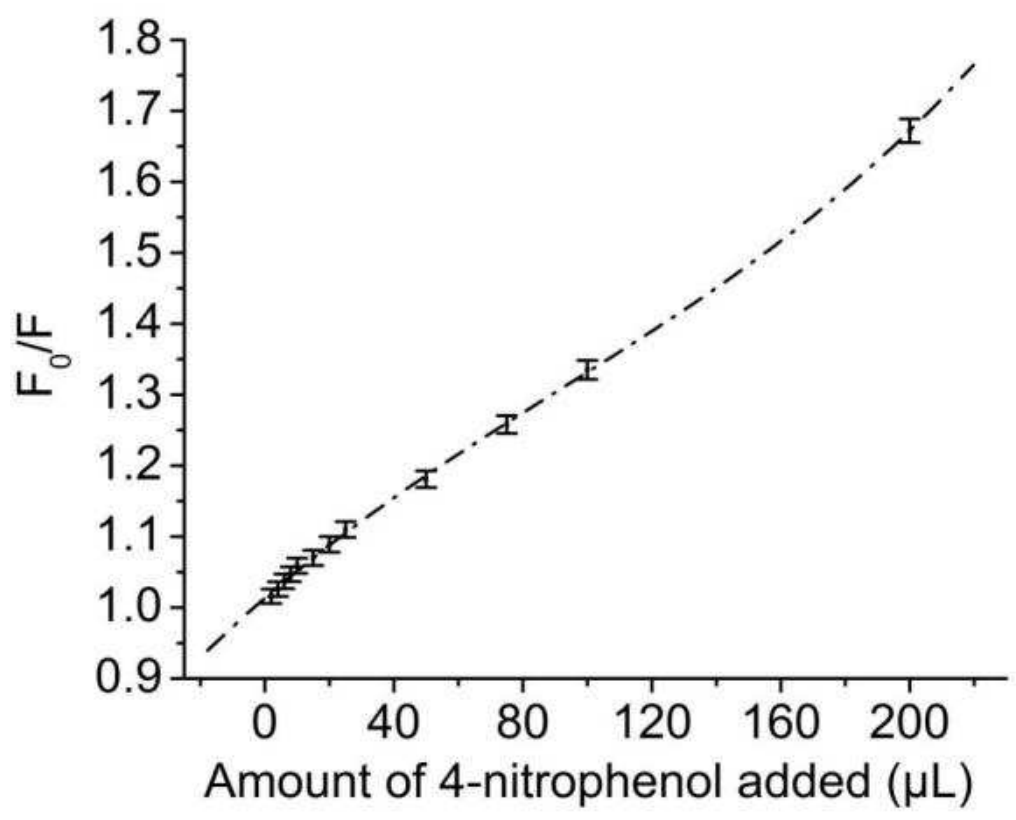

Figure 3. Stern-Volmer plot of the emission data provided by the addition of $0.066,0.133$, $0.199,0.265,0.332,0.497,0.662,0.826,1.639,2.439,3.225$ and $6.250 \mu \mathrm{M}$ of (2d) to (1) $(0.209$ $\mu \mathrm{M})$ in $\mathrm{CH}_{3} \mathrm{CN}(3 \mathrm{~mL})$ Final concentration of $\mathbf{2 d}$ was calculated after adding 2, 4, 6, 8, 10, 15 , $20,25,50,75,100,200 \mu \mathrm{L}$ equivalent of 4-nitrophenol (2d) stock solution $\left(1 \times 10^{-4} \mathrm{M}\right)$ to the stock solution of $1\left(2.09 \times 10^{-7} \mathrm{M}\right)$.

To investigate the intermolecular interactions triggering the ground-state complex formation, spectroscopic analysis of the 1, 2d and the possible complex (1:2d) were carried out by NMR 
and FTIR spectroscopy. Equimolar amounts of vacuum-dried 1 (10.64 mg, $\left.3.28 \times 10^{-2} \mathrm{mmol}\right)$ and $2 \mathrm{~d}\left(4.5 \mathrm{mg}, 3.28 \times 10^{-2} \mathrm{mmol}\right)$ were dissolved in $1 \mathrm{~mL}$ of freeze-dried $\mathrm{CDCl}_{3}$ for NMR spectroscopy analysis. Figure 4 illustrates the ${ }^{1} \mathrm{H}$ NMR spectra of 1, 2d and 1:2d. The ${ }^{1} \mathrm{H}$ NMR spectrum of 1:2d shows that the hydroxyl proton of $\mathbf{2 d}\left(\mathbf{H}_{\mathbf{a}}\right)$ at $5.74 \mathrm{ppm}$ disappears upon mixing with $\mathbf{1}$ suggesting a strong interaction between $\mathbf{1}$ and $\mathbf{2 d}$. The loss of $\mathbf{H}_{\mathbf{a}}$ signal can probably be attributed to $\mathrm{H}$-bonding between hydroxyl proton of $\mathbf{2 d}$ and ester carbonyl/amino functional groups of $\mathbf{1}^{15-20}$ since the possible proton exchange with water has been excluded by carrying out NMR experiments under dry conditions. It is also worth mentioning that $\mathbf{H}_{\mathbf{c}}$ protons undergo slightly upfield shifting (-0.04 ppm) while $\mathbf{H}_{\mathbf{e}}, \mathbf{H}_{\mathbf{j}}$ and $\mathbf{H}_{\mathbf{k}}$ protons undergo slightly downfield shifting $(0.04 \mathrm{ppm})$. However, shifts are not significant enough to relate with any possible $\pi-\pi$ interactions between $\mathbf{2 d}$ and $\mathbf{1}$. Furthermore, $\mathrm{NH}_{2}$ protons $\left(\mathbf{H}_{\mathbf{d}}\right)$ could not be assigned as an individual signal. Close inspections on integration of the two strong signals at $c a$. 3.70-4.00 ppm revealed that two more protons were present under the methyl proton signals $\left(\mathbf{H}_{\mathbf{g}}\right.$ and $\left.\mathbf{H}_{\mathbf{h}}\right)$. Surprisingly, those signals were no longer present at $c a$. 3.70-4.00 ppm upon the addition of $\mathbf{2 d}$ signifying an interaction, which is probably due to the participation of $\mathbf{H}_{\mathbf{d}}$ in H-bonding interaction. $^{19,21}$

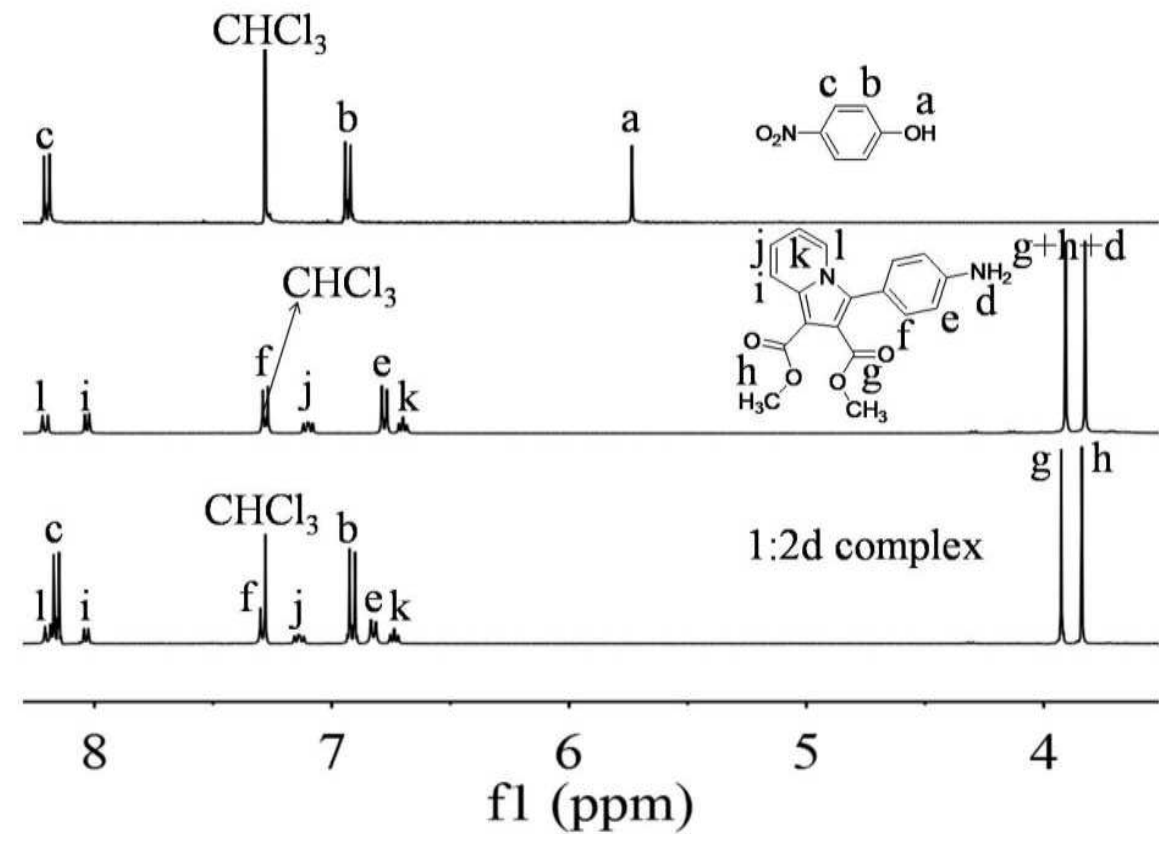

Figure 4. ${ }^{1} \mathrm{H}$ NMR spectra (400 $\mathrm{MHz}, \mathrm{CDCl}_{3}, 298 \mathrm{~K}$ ) of $\mathbf{1}, \mathbf{2 d}$ and the complex (1:2d).

FTIR spectroscopy analysis was performed also supported H-bonding interaction between $\mathbf{1}$ and $\mathbf{2} \mathbf{d}^{15-20}$ (See experimental procedure). FTIR spectrum of $\mathbf{1}$ displays two sharp $v_{\mathrm{C}=\mathrm{O}}$ stretching vibrations at 1726 and $1686 \mathrm{~cm}^{-1}$ due to the presence of methoxy ester carbonyls and two $v_{\mathrm{N}-\mathrm{H}}$ 
stretching vibrations at 3457 and $3369 \mathrm{~cm}^{-1}$ which are characteristic for aromatic amines (Fig. 6). As expected, the FTIR spectrum of the complex (1:2d) shows a broad $v_{\mathrm{C}=\mathrm{O}}$ stretching at 1690 $\mathrm{cm}^{-1}$ suggesting an intermolecular interaction between ester carbonyls with $\mathbf{2 d}$, probably through H-bonding. ${ }^{15-20}$ It is also noticed that the $v_{\mathrm{N}-\mathrm{H}}$ stretching vibrations shift to high energy region and appear at 3475 and $3379 \mathrm{~cm}^{-1}$ suggesting the participation of $\mathrm{NH}_{2}$ protons in host-guest interaction.

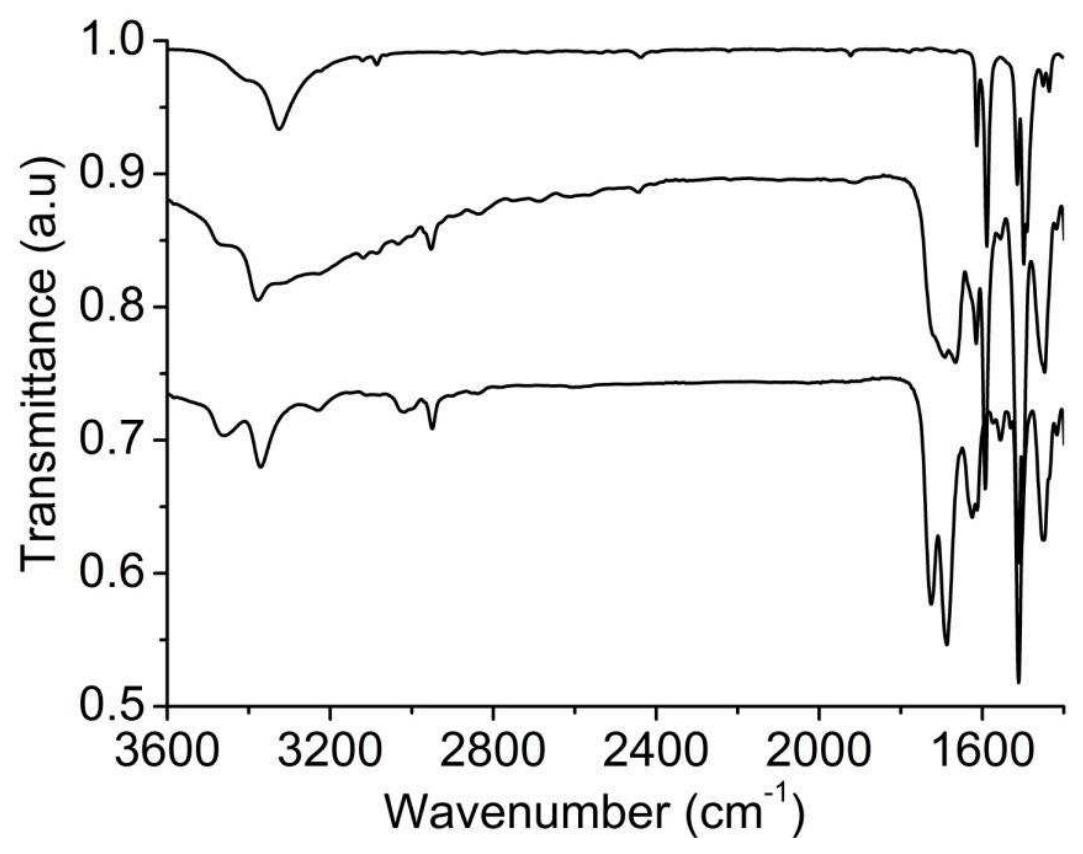

Figure 5. FTIR spectra of 1 (bottom), 2d (top) and the complex (1:2d) (middle).

\section{Conclusions}

Photoluminescence quenching of dimethyl 3-(4-aminophenyl)indolizine-1,2-dicarboxylate by electron-deficient phenol derivatives was shown in solution phase. This approach might open the way for the direct use of substituted indolizine skeletons as molecular probes. Consistent with HOMO-LUMO energies, ${ }^{1} \mathrm{H}$ NMR and FTIR analysis results suggest that the fluorescent quenching probably occurs via electron transfer from electron-rich indolizine to electrondeficient nitrophenolics through $\mathrm{H}$-bonding interaction between carbonyl/amine groups and hydroxyl. However, additional experiments including life time data, NMR titration are essential to establish the mechanism of electron transfer. Solid state photophysical properties of indolizines using carbon nanotubes as solid support which is currently under investigation in our lab, is also another interesting topic as indolizine modified nanotubes might be useful for the fabrication of sensing devices. 


\section{Experimental Section}

General. Phenol, $o$-nitrophenol, $m$-nitrophenol, $p$-nitrophenol, $p$-nitrotoluene and 2,4dinitrotoluene were purchased from Aldrich and used as received. Solvents were purchased from Sigma-Aldrich. ${ }^{1} \mathrm{H}$ NMR and ${ }^{13} \mathrm{C}$ NMR spectra were recorded on Bruker Avance-400 spectrometer operating at $\left({ }^{1} \mathrm{H}\right) 400.13 \mathrm{MHz}$ and $\left({ }^{13} \mathrm{C}\right) 100.62 \mathrm{MHz}$. Chemical shifts are reported in ppm relative to $\mathrm{CDCl}_{3}$ as internal standard, which was set to $7.28 \mathrm{ppm}$. High resolution mass spectra were recorded on a Micromass LCT premier instrument operating in ESI mode coupled to a time-of-flight (ToF) analyser. Infrared spectra of pure compounds (powder) were recorded using a Perkin Elmer Spectrum 100 equipped with a Pike ATR fitted with a Ge crystal. Infrared spectra of formed complexes were recorded as neat using $\mathrm{NaCl}$ windows. Melting points were detected using Reichert Auistria ( $\mathrm{Nr}$ 341869) melting point apparatus and not corrected. Fluorescence spectra were recorded on a Perkin Elmer LS55 luminescence spectrometer using an excitation wavelength of $330 \mathrm{~nm}$. Host indolizine (1) and guest (2a-f) compounds were freshly dissolved in acetonitrile $\left(\mathrm{CH}_{3} \mathrm{CN}\right)$ prior to fluorescent intensity measurement. HOMO-LUMO energy of compounds was calculated using ChemBio3D Ultra 13 software.

$N$-(4-Nitrobenzyl)-pyridinium bromide (4). The pyridinium salt (4) was prepared following a modified literature procedure. ${ }^{8}$ Pyridine (3) $(50 \mathrm{mmol})$ was added to $p$-nitrobenzyl bromide (45 $\mathrm{mmol}$ ) and the mixture stirred for $12 \mathrm{~h}$ at room temperature. The resulting off-white solid was washed with diethyl ether $(3 \times 20 \mathrm{~mL})$, ethanol $(3 \times 20 \mathrm{~mL})$ and acetone $(3 \times 20 \mathrm{~mL})$ to remove excess pyridine and $p$-nitrobenzyl bromide to afford the pyridinium bromide salt (4) (88\% yield); FTIR (ATR, $v_{\max }$ ): (NO) 1520 (sym), (NO) 1345 (asym) $\mathrm{cm}^{-1} ;{ }^{1} \mathrm{H}$ NMR (400 MHz, $\mathrm{D}_{2} \mathrm{O}$ ): 8.86-8.96 (d, 2H), 8.52-8.58 (t, $1 \mathrm{H}), 8.12-8.20(\mathrm{~d}, 2 \mathrm{H}) ; 8.02-8.10(\mathrm{~d}, 2 \mathrm{H}) ; 7.52-7.60(\mathrm{~d}, 2 \mathrm{H})$; 5.86-5.94 (s, 2H) ${ }^{13} \mathrm{C}$ NMR (400MHz, $\left.\mathrm{CDCl}_{3}\right)$ : 148.23, 146.62, 144.79, 139.89, 129.86, 128.77, 124.51, 63.45; $\mathrm{m} / z$ (TOF MS ES $\left.{ }^{+}\right)(\mathrm{MBr})^{+}: 215.0820$ calcd, 215.0813 found.

Dimethyl 3-(4-nitrophenyl)indolizine-1,2-dicarboxylate (5). At reflux temperature with vigorous stirring, triethylamine $(0.283 \mathrm{~g}, 2.8 \mathrm{mmol})$ was added to the pyridinium bromide salt (4) $(0.826 \mathrm{~g}, 2.8 \mathrm{mmol})$ in $10 \mathrm{~mL} \mathrm{CHCl}_{3}$ followed by drop wise addition of dimethyl acetylenedicarboxylate (DMAD) $(0.308 \mathrm{~g}, 2.8 \mathrm{mmol})$. After solvent removal, the product was eluted with EtOAc/hexane (2:1) and crystallized from diethylether (37\% yield) as orange powder; $\mathrm{R}_{\mathrm{f}} 0.58$ (EtOAc/Hexane 2:1); mp 209-210 ${ }^{\circ} \mathrm{C}$; FTIR (ATR, v $\max$ ): (CO) 1723, 1702, $\left(\mathrm{NO}_{2}\right)$ 1505, $1340 \mathrm{~cm}^{-1} ;{ }^{1} \mathrm{H}$ NMR $\left(400 \mathrm{MHz}, \mathrm{CDCl}_{3}\right): 8.39(\mathrm{~d}, J 8.90 \mathrm{~Hz}, 2 \mathrm{H}), 8.30(\mathrm{~d}, J 9.06 \mathrm{~Hz}$, $1 \mathrm{H}), 8.10(\mathrm{~d}, J 7.12 \mathrm{~Hz}, 1 \mathrm{H}), 7.75(\mathrm{~d}, J 8.93 \mathrm{~Hz}, 1 \mathrm{H}), 7.22(\mathrm{t}, J 7.94 \mathrm{~Hz}, 1 \mathrm{H}), 6.85(\mathrm{t}, J 6.87 \mathrm{~Hz}$, 1H), 3.94 (s, 3H), 3.86 (s, 3H). ${ }^{13} \mathrm{C}$ NMR $\left(100 \mathrm{MHz}, \mathrm{CDCl}_{3}\right): 166.29,163.83,147.69,135.99$, 135.91, 130.44, 124.40, 124.30, 123.45, 123.03, 122.25, 120.76, 114.37, 103.08, 52.70, 51.48; $\mathrm{m} / z\left(\right.$ TOF MS ES $\left.{ }^{+}\right)(\mathrm{M}+\mathrm{H})^{+}: 355.0924$ calcd, 355.0911 found.

Dimethyl 3-(4-aminophenyl)indolizine-1,2-dicarboxylate (1). Dimethyl 3-(4-nitrophenyl) indolizine-1,2-dicarboxylate (150 mg, $0.42 \mathrm{mmol})$ (5) was reduced into dimethyl 3-(4aminophenyl)indolizine-1,2-dicarboxylate (1) using the given literature procedure. ${ }^{9}$ After solvent 
removal, the product was eluted with EtOAc/hexane (2:1) and crystallized from diethylether (90\% yield) as pale yellow powder; $\mathrm{R}_{\mathrm{f}} 0.53$ (EtOAc/Hexane 2:1); mp 168-169 ${ }^{\circ} \mathrm{C}$; FTIR (ATR, $\left.v_{\max }\right):\left(\mathrm{NH}_{2}\right) 3457,3369$ (CO) 1726, $1686 \mathrm{~cm}^{-1} ;{ }^{1} \mathrm{H} \mathrm{NMR}\left(400 \mathrm{MHz}, \mathrm{CDCl}_{3}\right): 8.21(\mathrm{~d}, J 9.17 \mathrm{~Hz}$, $1 \mathrm{H}), 8.03(\mathrm{~d}, J 7.10 \mathrm{~Hz}, 1 \mathrm{H}), 7.28(\mathrm{~d}, J 8.5 \mathrm{~Hz}, 2 \mathrm{H}), 7.10(\mathrm{t}, J 7.89 \mathrm{~Hz}, 1 \mathrm{H}), 6.78(\mathrm{~d}, J 8.48 \mathrm{~Hz}$, $2 \mathrm{H}), 6.70(\mathrm{t}, J 6.79 \mathrm{~Hz}, 1 \mathrm{H}), 3.91(\mathrm{~s}, 4 \mathrm{H}), 3.83(\mathrm{~s}, 4 \mathrm{H}) .{ }^{13} \mathrm{C} \mathrm{NMR}\left(100 \mathrm{MHz}, \mathrm{CDCl}_{3}\right): 167.16$, $164.38,147.17,134.98,131.20,125.65,123.76,123.32,121.45,120.22,118.23,115.29,113.17$, 101.48, 52.43, 51.25; $\mathrm{m} / z$ (TOF MS $\left.E S^{+}\right)\left(\mathrm{MH}^{+}\right): 325.1182$ calcd, 325.1176 found.

General procedure for solution phase sensing. A stock solution of $(1)\left(2.09 \times 10^{-7} \mathrm{M}\right)$, and the guest molecules $(\mathbf{2 a - f})\left(1 \times 10^{-4} \mathrm{M}\right)$ were prepared in $\mathrm{CH}_{3} \mathrm{CN}$ for fluorescence spectral analysis. $3 \mathrm{~mL}$ solution of (1) was filled in a quartz cell of $1 \mathrm{~cm}$ optical path length, and stock solution of (2d) $(0.066,0.133,0.199,0.265,0.332,0.497,0.662,0.826,1.639,2.439,3.225$ and $6.250 \mu \mathrm{M})$ was added each time into quartz cell. Excitation wavelength of $330 \mathrm{~nm}$ and temperature of $25{ }^{\circ} \mathrm{C}$ were employed in all experiments. Emission spectra were recorded after shaking the mixture.

\section{Acknowledgements}

The authors thank to Dr. Alan Kenwright and Dr. Gareth Williams for their discussion on NMR and fluorescence data, respectively.

\section{References}

1. Liu, N.; Cai, X.; Zhang, Q.; Lei, Y.; Chan-Park, M. B. Electroanalysis 2008, 20, 558. http://dx.doi.org/10.1002/elan.200704080

2. Gundersen, L. L.; Malterud, K. E.; Negussie, A. H.; Rise, F.; Teklu, S.; Ostby, O. B. Bioorganic \& Med. Chem. 2003, 11, 5409.

http://dx.doi.org/10.1016/j.bmc.2003.09.033

3. Bayazit, M. K.; Coleman, K. S. J. Am. Chem. Soc. 2009, 131, 10670. http://dx.doi.org/10.1021/ja903712f

4. Sonnenschein, H.; Hennrich, G.; Resch-Genger, U.; Schulz, B. Dyes and Pigments 2000, 46, 23. http://dx.doi.org/10.1016/S0143-7208(00)00032-2

5. Padwa, A.; Austin, D. J.; Precedo, L.; Zhi, L. J. Org. Chem. 1993, 58, 1144. http://dx.doi.org/10.1021/jo00057a029

6. Delattre, F.; Woisel, P.; Bria, M.; Surpateanu, G. Carbohydrate Res. 2005, 340, 1706. http://dx.doi.org/10.1016/j.carres.2005.05.001

7. Surpateanu, G. G.; Landy, D.; Lungu, N. C.; Fourmentin, S.; Surpateanu, G. J. Het. Chem. 2007, 44, 783. 
http://dx.doi.org/10.1002/jhet.5570440405

8. Henrick, C. A.; Ritchie, E.; Taylor, W. C. Aust. J. Chem. 1967, 20, 2441. http://dx.doi.org/10.1071/CH9672441

9. Bellamy, F. D.; Ou, K. Tetrahedron Lett. 1984, 25, 839. http://dx.doi.org/10.1016/S0040-4039(01)80041-1

10. Vlahovici, A.; Druta, I.; Andrei, M.; Cotlet, M.; Dinica, R. J. Luminescence 1999, 82, 155. http://dx.doi.org/10.1016/S0022-2313(99)00027-7

11. She, N.; Gao, M.; Cao, L.; Wu, A.; Isaacs, L. Org. Lett. 2009, 11, 2603. http://dx.doi.org/10.1021/o1900858d

12. Woodward, R. B.; Hoffmann, R. J. Am. Chem. Soc. 1965, 87, 395. http://dx.doi.org/10.1021/ja01080a054

13. Principles of Fluorescence Spectroscopy; Lakowicz, J. R., Third Ed.; Springer: New York, 2006.

14. Evale, B. G.; Hanagodimath, S. M. J. Luminescence 2010, 130, 1330. http://dx.doi.org/10.1016/j.jlumin.2010.03.011

15. Hanagodimath, S. M.; Evale, B. G.; Manohara, S. R. Spectrochimica Acta Part A-Molecular and Biomol. Spectroscopy 2009, 74, 943.

16. Lommerse, J. P. M.; Price, S. L.; Taylor, R. J. Comput.l Chem. 1997, $18,757$. http://dx.doi.org/10.1002/(SICI)1096-987X(19970430)18:6<757::AID-JCC3>3.0.CO;2-R

17. Yoshimi, Y.; Maeda, H.; Sugimoto, A.; Mizuno, K. Tetrahedron Lett. 2001, 42, 2341. http://dx.doi.org/10.1016/S0040-4039(01)00179-4

18. Dharmalingam, K.; Ramachandran, K.; Sivagurunathan, P. Spectrochimica Acta Part A-Mol. Biomol. Spectroscopy 2007, 66, 48.

http://dx.doi.org/10.1016/j.saa.2006.02.019

19. Dasgupta, P. K.; Moulik, S. P.; Das, A. R. Bull. Chem. Soc. Japan 1991, 64, 3156. http://dx.doi.org/10.1246/bcsj.64.3156

20. Ilczyszyn, M. Journal of the Chemical Society-Faraday Transactions 1994, 90, 1411. http://dx.doi.org/10.1039/ft9949001411

21. Murthy, A. S. N.; Reddy, A. R. Advances in Molecular Relaxation and Interaction Processes 1982, 22, 199.

http://dx.doi.org/10.1016/0378-4487(82)80006-X 